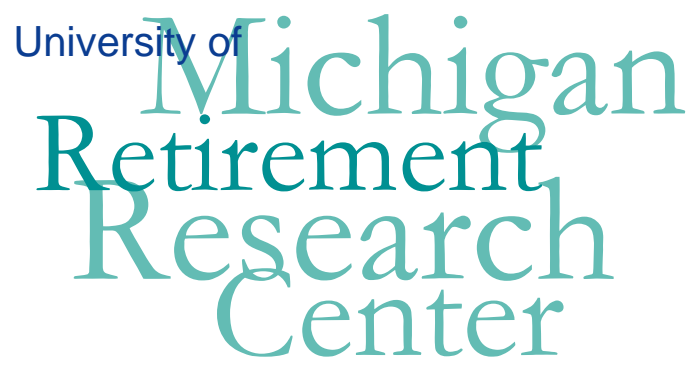

Working Paper

WP 2007-172

\title{
Housing Wealth and Retirement Timing
} Martin Farnham and Purvi Sevak

\begin{tabular}{|l|l|}
\hline $\mathrm{M}$ & $\mathrm{R}$ \\
\hline $\mathrm{R}$ & $\mathrm{C}$ \\
\hline
\end{tabular}$\quad$ Project \#: UM07-20 


\title{
Housing Wealth and Retirement Timing
}

\author{
Martin Farnham \\ University of Victoria \\ Purvi Sevak \\ Hunter College
}

October 2007

\author{
Michigan Retirement Research Center \\ University of Michigan \\ P.O. Box 1248 \\ Ann Arbor, MI 48104 \\ http://www.mrrc.isr.umich.edu/
}

(734) 615-0422

\section{Acknowledgements}

This work was supported by a grant from the Social Security Administration through the Michigan Retirement Research Center (Grant \# 10-P-98362-5-04). The findings and conclusions expressed are solely those of the author and do not represent the views of the Social Security Administration, any agency of the Federal government, or the Michigan Retirement Research Center.

\section{Regents of the University of Michigan}

Julia Donovan Darrow, Ann Arbor; Laurence B. Deitch, Bingham Farms; Olivia P. Maynard, Goodrich; Rebecca McGowan, Ann Arbor; Andrea Fischer Newman, Ann Arbor; Andrew C. Richner, Grosse Pointe Park; S. Martin Taylor, Gross Pointe Farms; Katherine E. White, Ann Arbor; Mary Sue Coleman, ex officio 


\title{
Housing Wealth and Retirement Timing
}

\author{
Martin Farnham and Purvi Sevak
}

\begin{abstract}
We use data from the Health and Retirement Study (HRS) and the Office of Housing Enterprise Oversight to measure the effect of changes in housing wealth on retirement timing. Using cross-MSA variation in house-price movements to identify wealth effects on retirement timing, we find evidence that such wealth effects are present. According to some specifications the rate of transition into retirement increases in the presence of positive housing wealth shocks. In addition, we use data on expected age of retirement to measure the impact of housing wealth shocks on expectations about retirement timing. Using renters as a control for heterogeneity in local amenities and using individual fixed effects to control for unobserved individual heterogeneity, we find that a $10 \%$ increase in housing wealth is associated with a reduction in expected retirement age of between 3.5 and 5 months.
\end{abstract}

\section{Authors' Acknowledgements}

*Corresponding author: psevak@hunter.cuny.edu

We are grateful to the Michigan Retirement Research Center for funding this research. We would like to thank participants in the Michigan Retirement Research Center workshop and members of the economics seminars at University of Victoria and Hunter College for helpful comments. All errors are the authors'. 


\section{Introduction}

House prices in the United States rose by an average of 40\% from 1995 to 2004

(Himmelberg, Mayer, and Sinai, 2005). This run-up in housing wealth produced many

millionaires, increased availability of secured credit to millions of households, and led to much

talk of a housing "bubble." Recent declines in housing prices in a number of key markets have

shaken financial markets, raised concerns about a possible recession in the US, and led to a

major softening in the construction sector.

The last decade has demonstrated that significant real increases in housing wealth can

occur over a relatively short period of time. History suggests that real housing wealth can also decline for significant periods of time. Given large observed swings in house prices, their effects on household behavior deserve consideration. In this paper we consider the effect of housing wealth shocks on labor supply. We specifically investigate whether changes in house prices affect the timing of retirement.

The empirical relationship between housing wealth and labor supply is of interest to both economists and policymakers. Housing constitutes a large fraction of the assets of the typical American family, and could therefore be an important source of wealth effects on labor supply. In the US and other western countries, there has been a long-run trend towards reductions in retirement age. The resulting decline in payroll tax collections coupled with an increase in life expectancy has put public pension systems under strain. Understanding the determinants of retirement timing is therefore a question of significant policy relevance. Housing wealth effects

\footnotetext{
${ }^{1}$ Economists disagree on whether pricing in US housing markets has recently constituted a bubble-loosely defined as a condition where asset prices exceed levels suggested by economic fundamentals. Case and Shiller (2003) present evidence suggestive of a bubble in housing markets. To the contrary, Himmelberg, Mayer, and Sinai (2005) argue that in spite of the significant run-up in house prices, the user cost of housing remains within its historical range in most real estate markets, and therefore there is little evidence of a bubble. However they do note that user cost of housing is highly sensitive to increases in interest rates and expectations of future capital gains, so that a substantial, lasting increase in interest rates or a change in expected gains could lead to large housing price declines. A price decline currently appears to be underway.
} 
on retirement timing may also be of interest to researchers studying the elderly home equityconsumption puzzle, in which older households are found to have a very low marginal propensity to consume goods and services out of housing wealth (Venti and Wise, 2000).

Changes in housing wealth should be expected to have an effect on consumption similar to other changes in permanent income. ${ }^{2}$ Standard lifecycle consumption theory predicts that permanent, unanticipated shocks to wealth should result in adjustment of consumption of goods and services as well as leisure. Assuming well-functioning capital markets, greater wealth should increase an individual's consumption of normal goods and services as well as their consumption of leisure, which we assume to be a normal good. Individuals may access increased housing wealth through financial products such as home equity loans or reverse mortgages. They may also access this wealth through informal borrowing markets. For instance, an elderly couple may intend to bequeath their home to their children when they die. If the couple experiences capital gains on their home but finds it difficult to access this newfound wealth through formal financial markets, they may turn to their children for financial assistance, on the understanding that the size of the children's expected inheritance has risen. Or households that were targeting certain bequest levels may be able to increase consumption of goods, services, and leisure if bequest targets are met sooner than expected due to housing wealth gains. Therefore, even without perfectly functioning formal financial markets individuals may be able to access newfound housing wealth through informal capital markets that facilitate increased consumption.

Of course, if such formal and informal capital markets are missing, then housing wealth changes may have little to no impact on consumption behavior, including consumption of leisure. Given the existence of capital market imperfections, the presence of housing wealth

\footnotetext{
${ }^{2}$ A caveat relating to the implied change in the user cost of housing associated with housing price changes, is discussed later.
} 
effects is an empirical question. A number of studies have tested for housing wealth effects on the consumption of goods and services. To date, little if any work has been done to ascertain the effect of housing wealth shocks on the consumption of leisure. In this paper we test for housing wealth effects on the timing of retirement.

We use data from the 1992 to 2004 waves of the University of Michigan's Health and

Retirement Study (HRS). This biennial survey provides detailed data on demographic, financial, and labor-supply characteristics of individuals who were between age 51 and 61 in 1992. Therefore the panel allows for study of a population with substantial housing wealth that is nearing retirement age. Using restricted access geocodes for the HRS, we merge house-price indices at the level of Metropolitan Statistical Area (MSA) from the Office of Federal Housing Enterprise Oversight (OFHEO) to the HRS data. This allows us to measure MSA-level house price changes for each household in the sample.

In the findings we present here, we find evidence of economically significant housing wealth effects on retirement timing. In some specifications we find an increased annual probability of retirement for workers with greater percentage gains in housing wealth since 1992. We also find that among non-retired workers, the expected age of retirement declines in the face of housing wealth gains.

\section{Review of Existing Wealth Effects Literature}

Though little work has been done specifically to measure the effect of housing wealth on the consumption of leisure, there is a rich literature examining general wealth effects on consumption. Estimating causal effects of wealth is made difficult by the fact that some variation in household wealth reflects individual heterogeneity in preferences that is likely correlated with 
labor supply and saving decisions. In the context of retirement behavior, high levels of wealth could cause early retirement, or plans to retire early could cause high levels of wealth. All else equal, one individual who plans to retire sooner than another individual should save more during her working years, because she will have more years in retirement during which she must live off of her accumulated wealth. Alternatively, wealthy individuals may have strong tastes for work and thus retire later. Thus, cross-sectional estimates of the effect of wealth on retirement timing could be biased in either direction. In order to convincingly identify a causal relationship running from wealth accumulation to early retirement, studies must rely upon exogenous variation in wealth. Recent papers examining retirement timing have relied on arguably exogenous increases in stock values, policy changes, inheritances and lottery winnings for identification purposes. A substantial literature in macroeconomics attempts to estimate the marginal propensity to consume out of changes in wealth. Much of this literature has focused on the effect of unexpected increases in stock market wealth on consumption. For example, Maki and Palumbo (2001) use the Survey of Consumer Finances to estimate a marginal propensity to consume (MPC) of 3 to 5 cents per dollar of stock market gains. Using detailed consumption data from the Consumer Expenditure Survey, Dynan and Maki (2001) estimate larger wealth effects. They find an MPC of 5 to 15 cents per dollar of stock market gains for households with moderate security holdings.

In the past two decades, several authors have tried to measure the effect of housing wealth on consumption of goods and services. Some of these studies have been done at the macro level (e.g. Bhatia 1987; Case, et al. 2005; Fisher, et al. 2005). Others have used micro data (e.g. Skinner 1996; Engelhardt 1996; Disney, et al. 2003; Belsky and Prakken 2004; Lehnart 2004; Bostic, et al. 2005). Most of these papers find a marginal propensity to consume out of 
housing wealth that is statistically significant and in the neighborhood of 0.06 . Some, such as Lehnert (2004) and Bostic et al.(2005) note the importance of credit constraints in the link between housing wealth and consumption. Some, such as Lehnert (2004) and Skinner (1996) note differences by age in the propensity to consume out of housing wealth. Others, such as Engelhardt (1996) and Disney, et al.(2003) find that households with negative equity exhibit a disproportionate increase in saving in response to housing wealth losses. Fisher et al. stands out as an exception in this literature. They argue that because most of the recent change in housing wealth in Australia is transitory rather than permanent, consumption (at least recently) has not been very responsive to changes in housing wealth.

A recent paper by Morris (2006) is worthy of mention here. Morris constructs a theoretical model of consumption as a function of housing wealth. She shows that because the user cost of housing rises when house prices rise, the real wealth gain associated with an increase in house prices can be substantially smaller than the actual capital gain on the home. In the extreme case of an infinitely-lived household, capital gains on the home will be perfectly offset by the present discounted value of the increase in future user costs, so the theoretical wealth effect on consumption is zero. A similar argument extends to finitely-lived but dynastic households (assuming offspring will live in the same housing market and therefore face the same housing costs). Finitely-lived, non-dynastic households, however, will experience a real increase in housing wealth when they experience housing capital gains. Morris shows theoretically that the marginal propensity to consume out of housing gains will be increasing in age (because of the shorter time horizon of older households, the annuity value of a housing gain is higher and the associated lifetime increase in user costs is smaller) and increasing in the propensity to migrate to regions with lower housing costs (because this implies lower future user costs of 
housing). She finds supporting evidence in fixed effects estimates of the marginal propensity to consume out of housing gains using the PSID. In particular she estimates a marginal propensity to consume out of housing gains of approximately 0.13 for households over 50 years of age.

A number of papers have provided estimates of the effect of non-housing wealth on retirement. Earlier papers examined the effect of unexpected increases or decreases in Social Security on retirement timing. Hurd and Boskin (1984) find that Social Security benefit increases from 1969 to 1972 can explain a large amount of the acceleration of retirement in that period, whereas Burtless (1986), using the same data, finds that the effects were very small. Kruger and Pishke (1992) estimate the effect of reductions in benefits due to amendments to Social Security in 1977 and find no effect.

More recent papers have found exogenous variation in wealth through a variety of natural experiments. Imbens, Rubin, and Sacerdote (2001) survey lottery winners and find significant labor supply effects of winnings, particularly among individuals ages 55 to 65 . A paper by Kimball and Shapiro (2001) makes use of survey questions on hypothetical lottery winnings and finds large responses to wealth gains. Holtz-Eakin, Joulfaian and Rosen (1993) find that individuals in households that receive large inheritances are more likely to leave the labor force and less likely to enter the labor force than other households.

A number of papers have exploited the stock market "bubble" of the late 1990s to test for wealth effects on retirement timing. Using a difference-in-difference analysis, Sevak (2005) finds earlier retirement among workers with defined contribution (DC) pension plans relative to those with defined benefit (DB) pension plans in 2000 compared to the early 1990s. She also finds that those with greater increases in their stock holdings and IRAs during the 1990s were more likely to retire. Coronado and Perozek (2001) also find earlier retirements among 
individuals who were most likely to gain from the performance of the stock market - stock holders or those with defined contribution pension plans. Hurd and Reti (2001), on the other hand, find that the stock market had no significant effect on retirement timing.

Given the evidence that stock market windfalls speed up retirement, it seems possible that housing windfalls will have similar effects. Compared to the empirical literature on stock market wealth effects on labor supply, relatively little empirical work has been done to measure housing wealth effects on leisure. To our knowledge only one paper has directly studied the impact of housing wealth on retirement timing. Doling and Horsewood (2003) use aggregate data from a cross-section of European countries to argue that the declines in retirement age can be attributed to increased homeownership rates. However, they do not attempt to directly measure a housing wealth effect.

The housing boom of the 1990s and early 2000s provides an opportunity to reexamine the question of wealth effects on retirement timing. To the extent that the boom in real estate markets can be considered an exogenous shock to wealth (we discuss this further below), we can use variation in housing price changes across regions to identify a housing wealth effect on retirement timing.

In addition, the housing boom and current decline present potential challenges to policymakers. To the extent that individuals respond to increases in housing wealth by dropping out of the labor force, pressure on public pension systems due to declining payroll tax receipts may increase. To the extent that decisions to exit the labor force are not fully reversible, then any future retrenchment in the housing market may have important impacts on the financial security of older households who had counted on their home equity to finance consumption of goods and services in retirement. To the extent that housing wealth effects on retirement timing have been 
large during the housing boom, the risk associated with retrenchment may also be large.

Therefore, beyond providing a potential natural experiment from which to learn about wealth effects, the housing boom of the 1990s in itself presents important policy issues worthy of study.

\section{Data}

In order to examine the effect of changes in housing wealth on the retirement timing of older individuals, we assemble a data set based on observations on individual workers from the University of Michigan's Health and Retirement Study (HRS) for the years 1992 to 2002. The HRS is a panel containing extensive data on income, wealth, work and health status, and other characteristics of individuals near retirement age. ${ }^{3}$ In addition, the survey codes geographic identifiers in each wave that allow matching to the local-level data on house prices and local labor markets that we use in our analysis.

Because the HRS is an ongoing panel survey, construction of an analysis file can be a complex process. A baseline set of 7,650 randomly selected households with a member born between 1951 and 1961 were interviewed in 1992. Every two years, the HRS attempts to reinterview the members of this household. Though the re-interview rate is quite high (see Table 1, discussed below), in some cases a household or individual household member may refuse to conduct an interview or may be unreachable. If this is the case, the HRS continues to interview them in subsequent waves. The HRS provides a "tracker" file, which summarizes the interview status of each household member over time and facilitates the merge of multiple years of data. It includes data on whether the person was interviewed, and reasons for non-interview including whether the individual has died or is in a nursing home.

\footnotetext{
${ }^{3}$ Extensive information on the HRS data is given at $\mathrm{http}: / / \mathrm{hrsonline}$.isr.umich.edu/data/index.html.
} 
In each interview year, respondents answer detailed questions about current and past labor supply, health, and other topics. A designated "financial respondent" in each household provides detailed financial information on the household. This includes values of various assets, including housing, real estate, stocks, bonds, checking and savings accounts, individual retirement accounts (IRAs), small businesses, and pensions. Since housing assets are reported at the household level and cannot be attributed to one particular spouse, we measure housing wealth and all other household wealth at the household level and assume that households pool their resources.

Since year of retirement is available on an annual basis, and yet HRS surveys are conducted biennially, we annualize the dataset by imputing values of other individual characteristics for the odd-numbered years (in which respondents are not surveyed). The imputation of values is done linearly using data from the previous and next survey years. For example, values for 1995 would be imputed linearly from 1994 and 1996 survey values. Timing of retirement does not need to be imputed, because respondents report the year they retired. ${ }^{4}$

The stock of retirees among male HRS respondents in our analysis sample is plotted in Figure 1. At age 52 (the youngest age of HRS respondents in our analysis sample) approximately $18 \%$ of the sample self-identifies as retired. By age 61 this has risen to around $41 \%$. By age 73 (the oldest age of HRS respondents in our sample) this percentage has reached nearly $90 \%$. Transitions into retirement by age, expressed as percentage of the analysis sample that has not retired by 1992, are shown in Figure 2, where we see that transitions into retirement accelerate as individuals near their sixties. There is a spike in retirement transitions around age 62, presumably

\footnotetext{
${ }^{4}$ We also linearly interpolate values when a respondent has missed an interview for one wave but has completed interviews for the waves before and after it.
} 
corresponding to the start of eligibility for Social Security benefits, and a subsequent spike at 65 . Transitions into retirement then taper off after age 65 .

We merge two sets of external data to the HRS panel. First, we use annual county-level unemployment data from the Bureau of Labor Statistics (BLS) to control for local labor market conditions, which may affect retirement timing. Second, we merge data on local house prices from the Office of Federal Housing Enterprise Oversight (OFHEO). The OFHEO calculates a quarterly house price index (HPI) using data on repeat sales of single family homes. These data are provided to OFHEO by Freddie Mac and Fannie Mae and are based on sales of homes that have standard mortgages. The HPI is a weighted average across actual houses of changes in house prices. Because it relies on repeat sales, it is a "constant quality" index, avoiding the problem of a changing quality of housing stock that one would get if just looking at average prices of sold homes over time. ${ }^{5}$ The HPI is available at the state level and the MSA level. Thus, for each HRS household we can measure the change in house prices that occurred over a given period of time in their metropolitan statistical area or state. ${ }^{6}$ Since the HRS tracks moves by households across MSAs, we are able to assign to movers in our sample cumulative housing gains across prior locations as well as the current location. The use of the HPI will prove useful even though HRS respondents report their house values in each wave, for reasons discussed in the next section.

The permanent income hypothesis predicts that households will alter consumption in response to unanticipated changes in wealth. Assuming well-functioning capital markets, anticipated changes in wealth should already be factored into the current consumption path. If

\footnotetext{
${ }^{5}$ The OFHEO methodology is a modified version of the weighted-repeat sales (WRS) methodology originally proposed by Case and Schiller (1989). A full technical description of the HPI is available at http://www.ofheo.gov/Media/Archive/house/hpi tech.pdf.

${ }^{6}$ The HRS reports county of residence in a restricted access dataset that can only be obtained after a thorough review. More information is available at http://hrsonline.isr.umich.edu/rda/.
} 
overall house price changes are comprised of an anticipated and an unanticipated component, then we should expect to find retirement timing responding to the unanticipated component only. In some of our analysis, we measure the impact of overall housing price changes on retirement timing. In other analysis, we measure the impact of unanticipated housing price changes on retirement timing. To construct a series of unanticipated housing price changes, we regress MSA-level house price changes on a state-specific linear trend. We interpret the residual from this regression as denoting annual unanticipated price changes. From these residuals, cumulative percent changes since our analysis base year of 1992 are calculated. These are used as a measure of cumulative unanticipated changes in house prices.

This approach to deriving unanticipated changes in house prices assumes that households formulate expectations about future house price changes on the basis of the observed average housing price trend within their state. While this is probably not an entirely accurate representation of the expectations formation process, it is likely that observed price changes over time within their state figure prominently in household formation of expectations about house price changes in their own MSA. Summary statistics on our unanticipated price change series are presented below.

Table 1 illustrates our sample selection. We focus on men because men of this generation tend to have had a stronger attachment to the labor force than women. In addition retirement may be an ill-defined concept for someone who works mostly in the home. In the first survey wave (1992) 4,602 men born between 1931 and 1941 were selected to be surveyed. The sample remaining in the workforce (non-retired) declines over time, as would be expected. Of these nonretired individuals, those who remain in the sample and report working also decline over time. Further sample reductions occur when we limit workers to those who are not self-employed, 
those who are homeowners, and those for whom the HRS has valid county codes (and hence can be matched to local unemployment data) and who have no other missing data. This leaves us with a sample of 10,326 observations spanning the years 1992-2002. It is worth noting that since the sample shrinks substantially by the year 2000 (because individuals fall out of the sample upon retirement) we are identifying wealth effects primarily off changes during the 1990s. Much of the boom in housing prices in the early 2000s is unexploited in this study.

While our sample selection may appear quite severe, once we limit the sample to men, most of the further sample selection involves removal of individuals to whom our empirical question does not apply. Questions of housing wealth effects on retirement timing clearly do not apply to non-homeowners, non-workers or workers who have already retired. These groups account for the vast majority of the observations we omit from our analysis. We also omit selfemployed individuals because we expect their behavior with respect to retirement timing to differ substantially from that of wage and salary workers. While our primary analysis is limited to men, we do expand it to include women in some of the analysis that follows.

Summary statistics for our analysis sample of men are given in Table 2 . These summary statistics refer to the sample in the last column of Table 1. The analysis sample includes male workers who are not self-employed, who are from a home-owning household, and who do not have missing data. The mean age of respondents in our sample is 59 years. The mean expected retirement age is 63.2. The mean level of home equity (in 2002 dollars) in 1992 is about $\$ 76,000$. Based on MSA-level house price data from the OFHEO matched to HRS individuals, the average cumulative percent change in house value in our sample is $2.55 \%$. House price data have been deflated using the nonhousing CPI. Keep in mind that average cumulative changes in house value in our analysis sample include small values in the early years of the sample, negative 
values for some markets that were falling through the mid-1990s, and larger values in the later years (as the housing prices pick up in some markets and as more significant gains accumulate over time). The overall real house price change between 1992 and 2000 is $10.3 \%$ on average. The average unanticipated cumulative percent change in house value is $-0.71 \%$. The average unanticipated cumulative percent change between 1992 and 2000 is $-1.7 \%$. The mean unemployment rate in counties where HRS respondents live is $6 \%$ over the sample period.

Table 3 gives a more detailed distribution of the household wealth levels and changes. The median level of home equity in 1992 was $\$ 55,500$. The median cumulative change in house value since 1992 was $1.3 \%$. The median cumulative unanticipated change in house value since 1992 was $-0.5 \%$. The median overall change in house value from 1992 to 2000 was $10.3 \%$ (not shown in Table 3). The median overall unanticipated change in house value from 1992 to 2002 is $-1.9 \%$.

\section{Empirical Strategy}

The measurement of housing wealth effects on retirement timing is subject to a number of challenges. First, housing prices may be correlated with local labor market conditions. Local home values may reflect current or future labor market opportunities, which may also be correlated with retirement timing. If older individuals delay retirement in the face of high wages and if high wages are capitalized into local house values, then failure to control for local labor market conditions may lead to downward bias in estimates of wealth effects. As a result, in the specifications reported below we control for the worker's wage in the previous year and for the local (county-level) unemployment rate. 
Second, changes in housing prices may be correlated with changes in unobserved local amenities that also affect an individual's retirement timing decision. Since we cannot control for changes in local amenities we introduce a control group in some specifications who should respond to changes in local amenities but who should not respond to changes in housing prices. By including renters, who should not respond to housing wealth effects, in the analysis, we can difference out the change in retirement timing that is due to unobserved changes in local amenities capitalized into local housing values. The difference between the responses of owners and renters to changes in local housing prices can be interpreted as a wealth effect on retirement timing that is purged of bias due to unobserved heterogeneity in local amenities.

Third, housing wealth, defined as the value of equity in one's home, is likely to be endogenous due to the fact that it is, in part, a choice variable of households. Households, to the extent they can liquidate equity in their home through borrowing or increase equity through mortgage pre-payments, may be able to adjust their housing wealth in ways correlated with their preference for leisure. Households anticipating early retirement may pay off their mortgage more quickly than households anticipating later retirement. To the extent that home equity or changes in home equity reflect active management of one's housing wealth, these measures may reflect expected retirement timing of households. This would potentially lead to upward bias in measurement of housing wealth effects. As a result, rather than measuring the effect of changes in home equity on retirement timing, we measure the effect of changes in house value on retirement timing. Since, among non-movers, these are arguably exogenous changes in household wealth, estimation of housing wealth effects based on change in house value should not be subject to this upward bias. 
Fourth, self-reported data on house values, while providing variation in wealth at the individual level, is subject to classical measurement error. This will lead to downward bias in the estimates of wealth effects on retirement timing. Initial work with the HRS self-reported house value data suggests that measurement error exists and as is often the case with measurement error, it is particularly problematic when considering changes in house value over time. An extensive discussion of mismeasurement in self-reported data on house values can be found in Engelhardt (2005). As a result of the measurement error present in the HRS, we have chosen to use OFHEO house price indices (HPI) described in the last section to proxy for changes in house values. In addition to lessening the measurement error problem, use of the MSA-level data means that we do not need to account for additions or improvements that individuals have made to their homes. This would be an issue with the use of self-reported home value data, and would add another potential source of endogeneity, as improvements are a form of active management of the value of the home.

We merge the HPI to HRS households based on the state and county the household lives in at the time of the interview. The HPI is available at the MSA level and the state level, so for households that live in counties that are in MSAs, our measure of changes in house values is quite local. For non-MSA dwellers, we must rely on state-level changes in house value. Though we do not rely on self-reported data to calculate changes in house value, we do use the household's self-reported 1992 level of housing equity as a control in the specifications discussed below.

A fourth issue is the need to distinguish between anticipated and unanticipated changes in housing wealth. In some specifications, we model retirement (or expected age of retirement) as a function of cumulative changes in overall house prices. In other specifications, we use 
cumulative unanticipated changes in overall house prices as an independent variable. The derivation of this series is described in Section III. A further issue is distinguishing between permanent and transitory changes in wealth. House prices may jump in response to a temporary shortage of housing. Over time, as housing supply adjusts to the increase in prices, an anticipated decline in prices will occur, undoing the original jump in price. Such transitory changes in prices should not affect lifecycle consumption and therefore should not affect the timing of retirement. Papers in the micro housing wealth literature have not, to date, dealt with this issue. Fisher, Otto and Voss (2006) address this point in the context of housing wealth and consumption in Australia. In the current draft, we do not address this particular issue, though we discuss this point in the context of anticipated further work in our concluding remarks.

The first basic specification we use in our analysis is a linear probability model of entry into retirement. We use this model instead of a non-linear model primarily for the sake of ease of interpretation. For this basic specification, we use the following model of entry into retirement:

$$
D_{i t}^{\text {RETREE }}=W_{i, 1992}^{\prime} \beta+\phi \triangle H P I_{i, t-1992}+X_{i t}^{\prime} \delta+u_{i t} .
$$

Our primary analysis sample includes male workers who have not retired by $t-1$ and are working at $t-1$. We define a worker as retired of he considers himself either partially or fully retired. Thus, we only include the first entry into retirement in our sample. We pool observations from 1994 to 2002. We exclude 1992 because we use lagged values for some variables discussed below, and 1992 is the first year we observe these workers.

$D^{R E T I R E}$ is a dummy variable equal to 1 if individual $i$ retires at time $t$ and equal to zero otherwise. $W$ is a vector of household wealth variables in real (2000) values. Measures of 
household wealth include home equity, business wealth, and other wealth in 1992. $\triangle H P I$, the variable of primary interest, denotes change in housing wealth. It is measured as the cumulative percent change in housing wealth since 1992, calculated from the OFHEO MSA-level and Statelevel house price indices.

We choose to denote changes in housing wealth in percentage terms, rather than in dollar terms. We could have inflated 1992 self-reported house values in the HRS by the matching OFHEO house price index and calculated the effects of dollar changes in housing wealth on retirement timing. We choose a percent change specification of the wealth variable because we expect that relative changes in housing wealth matter more than absolute changes. In other words, a $\$ 50,000$ increase in housing wealth will probably have a larger impact on the retirement timing choice of someone with a $\$ 100,000$ home in 1992 (for whom it is a 50\% increase in housing wealth) than someone with a \$1,000,000 home in 1992 (for whom it is only a 5\% increase). To be precise, a $5 \%$ cumulative change in housing wealth would be denoted as " 5 " in the data. In some specifications, we use the measure of unexpected cumulative percent change in house value described in Section III.

$X$ is a vector of control variables. Controls in our specifications include years of education, lagged log wage, the county-level unemployment rate and dummy variables denoting individual year-of-age, race, lagged marital status, and a lagged indicator of poor health. We also include year fixed effects and controls for lagged industry and lagged occupation. In some specifications we add state fixed effects.

Estimates of this model are performed using OLS. Standard errors are clustered at the MSA level to account for the fact that we have multiple observations on individuals using the same measure of house-price change. Results from this specification using overall cumulative 
percent change in house price are given in Table 4. Results from this specification using unanticipated cumulative percent change in house price are given in Table 5. Both sets of results are discussed in the next section.

The empirical strategy outlined thus far investigates the relationship between housing wealth changes and actual retirement timing. Another way to consider the effect of changes in housing wealth on retirement timing is to exploit data in the HRS on expected retirement timing. Workers in each survey wave of the HRS are asked at what age they intend to retire. Since worker expectations vary at a greater frequency than actual retirement status (transition to retirement can only occur once given the way we structure our analysis sample), we may be able to measure housing wealth effects on retirement timing with greater precision using these data. In addition, the use of retirement expectations allows us to observe responses to housing wealth effect before actual retirement occurs. This eliminates the problem of right censoring that occurs with individuals in our sample whose future retirement (beyond the sample period) may, in fact, be affected by housing wealth changes, but whose retirement we never observe. This right censoring could be expected to lead to downward bias in our estimates of wealth effects on actual retirement transitions. The annual within-individual variation in expected retirement age also allows for inclusion of individual-level fixed effects, which may reduce bias due to unobserved individual heterogeneity.

Figure 3 shows a comparison of the distribution of actual retirement ages and expected retirement ages (as of 1992) for the subsample who retire during the survey period and who state their expected age of retirement in 1992. The correlation between expected and actual retirement ages is about 0.56 . As Figure 3 illustrates, there are no systematic deviations between actual and expected retirement ages. Some of the slippage of expected retirement at age 62 to actual 
retirements at age 61 and age 63 may be attributable to measurement error. Actual retirement age is likely to be less precisely measured than expected retirement age. But expectations and realizations appear to be systematically related, thus providing some support for analyzing expectations as a way around the right censoring problem.

To estimate the impact of housing wealth changes on expected retirement timingnamely expected retirement age - we estimate variants of the following empirical model of expected retirement age:

$$
E\left[A g e_{i t}^{\text {retire }}\right]=W_{i, 1992}^{\prime} \beta+\phi \Delta H P I_{i, t-1992}+X_{i t}^{\prime} \delta+v_{i t}
$$

Right-hand-side variables are the same as in Equation (1). The left-hand-side variable is the age, in years, at which the respondent (at time $t$ ) expects to retire.

Estimates of this model are also performed on the analysis sample described in Section III, using OLS. Again, we cluster our standard errors to account for the fact that we have multiple observations on individuals within MSAs. Results from this specification are given in Table 6 and 7. Results of a specification that includes individual fixed effects are given in Table 9.

\section{Estimation Results}

The estimates we display in tables below are for an analysis sample of male workers in the HRS. In most cases we focus on non-self-employed, non-retired male workers who are also homeowners. At the end of this section, we discuss results (not shown here) including non-selfemployed, non-retired female workers. 
Table 4 gives estimates of equation (1), the linear probability model of transition into retirement, where the key independent variable of interest is the overall cumulative percent change in house price. Column 1 gives results without including the county-level unemployment rate or state fixed effects. The estimated coefficient on the cumulative house-price-change variable is 0.0007 . This would suggest that a $10 \%$ increase in housing wealth leads to an increase of 0.007 in the annual retirement probability. Given the mean retirement probability in our sample of 0.108 , this would be a $6.5 \%$ increase in the annual probability of retirement. The coefficient estimate is statistically significant at the 5 percent level. In Table 4 , Column 2 we give results for a specification that includes a control for the local unemployment rate. Again, we find a statistically significant increase in the annual probability of retirement of $6.5 \%$. However, when we add state fixed effects in Table 4 Column 3, the magnitude of the coefficient declines by more than half and the estimate is statistically insignificant.

Results for covariates are generally not surprising. Married men are less likely to retire and those in poor health are more likely to retire. Education has no predictive value on the oneyear retirement transition. Higher wage workers and black workers tend to retire earlier.

It is important to note that the coefficient estimates on the cumulative percent change in house prices given in Table 4 represent the average effect of overall housing price changes, which arguably include both anticipated and unanticipated components. The permanent income hypothesis predicts that, in the absence of credit constraints, only unanticipated asset price changes should affect retirement timing. Therefore it is worth separately considering the effect of unanticipated changes in housing wealth. Recall that unanticipated changes in house prices are obtained from regressing annual MSA-level price changes on state-specific trends. The residuals from this regression are interpreted as unanticipated changes in house prices. 
Results using this specification of the house-price change variable are given in Table 5. Column 1 gives results of a specification of equation (1) that omits the county-level unemployment rate and state fixed effects. In this specification, we obtain a coefficient estimate on change in house price variable of 0.0010 . This estimate is statistically significant at the 5 percent level. The coefficient estimate implies that a $10 \%$ unanticipated increase in house price increases the annual retirement probability by $9 \%$. Consistent with the permanent income hypothesis, this coefficient estimate is substantially larger than that obtained in Table 4, Column 1, using the measure of house price change that includes both anticipated and unanticipated components. However, given the distribution of our measure of unanticipated house price changes (see Table 3), it is worth noting that a $10 \%$ unanticipated change in house prices is a very large change.

Table 5 Column 2 gives results with county-level unemployment rate added to the specification. The coefficient size and significance are close to those in Column 1. As in Table 4 though, when state fixed effects are added in Column 3, the estimated effect of housing wealth changes on retirement transitions is statistically insignificant. This is due more to an increase in the standard error of the estimate than it is to a decrease in the magnitude of the coefficient estimate.

As stated in the last section, modeling the actual transition into retirement has some limitations. Because some of the workers in our sample do not reach retirement during the sample period, the model is right censored. Thus we observe zero effect for men who have not yet retired but who may actually retire earlier (but beyond the sample frame) because of increases in housing wealth. This biases the estimates toward zero. Because of this, we also examine wealth effects on expected age of retirement. Table 6 gives estimates of Equation 2 
obtained by OLS. Equation 2 models expected retirement age as a function of changes in housing wealth. Note that the sample size shrinks to 7,427 . This is due primarily to the fact that we now only include respondents who are not yet retired when they appear in the sample. In the sample used to estimate retirement transitions, individuals also appeared in the sample in the period in which they first declared their retirement.

Results in Table 6, Column 1, are for the specification of Equation (2) that omits countylevel unemployment rate and state fixed effects. The coefficient estimate of -0.033 on cumulative percent change in house price (which includes both expected and unexpected changes) suggests that a 10\% cumulative increase in house prices since 1992 leads to a decline in expected retirement age of 0.33 of a year ( 4 months). Inclusion of county-level unemployment rate does not substantially change our findings, as can be seen in Table 6 , Column 2. In both cases, the estimated housing wealth effects are statistically significant at the five-percent level. In Column 3, we add state fixed effects. Here, the coefficient estimate declines in magnitude and the standard error of the estimate rises, so that the effect we estimate is statistically insignificant.

In Table 7, we present results of OLS estimation of equation (2) using as the key righthand-side variable our measure of cumulative unexpected changes in house price. Here we find larger effects, consistent with the permanent income hypothesis. In all three specifications in Table 7, we find that a $10 \%$ unanticipated increase in house price leads to a reduction in expected retirement age of just over 6 months. This finding is statistically significant at the 5 percent level in all three specifications, including that with state fixed effects.

While we attempt to control for local labor market conditions using the county unemployment rate and individuals' lagged wages, it may be the case that other factors correlated with both retirement timing and housing wealth are omitted from the above analysis. 
For instance, improvements in local amenities and leisure opportunities in an area may be capitalized positively into house values. At the same time, these changes may induce people to retire earlier. Failure to control for these changes would likely cause upward bias in the magnitude of the estimated coefficients on housing price changes in both of the basic specifications discussed above.

One way to address this problem is to introduce renters into the analysis as a control group. Renters, by definition, do not experience housing wealth changes associated with changes in local amenities. Yet, their retirement behavior would be expected to respond to such changes. If housing wealth changes are merely reflecting changes in local amenities tied to retirement timing decisions, then renters and owners should respond similarly to changes in housing wealth. To the extent that housing wealth changes are independent of changes in local amenities tied to retirement timing (i.e. exogenous), then owners' retirement timing should respond to housing wealth changes, while renters' retirement timing should not. ${ }^{7}$

If we find that renters and owners respond similarly to housing wealth effects, this would suggest that the relationship we detect between housing prices and retirement timing is spurious. If we find housing wealth effects for owners but not for renters, this would suggest that our findings are not being driven by failure to control for changes in local amenities. The difference between the housing wealth effect for owners and that for renters can be viewed as a differencein-difference estimator of the housing wealth effect on retirement timing that controls for unobserved changes in local amenities.

\footnotetext{
${ }^{7}$ Or, in the case of renters who are saving up to buy a home, the response of renters' retirement timing to local changes in house prices should be in the opposite direction of the response of owners' retirement timing.
} 
Results from specifications based on equations (1) and (2) using renters as a control group are given in Table 8. The first two specifications consider the effect of housing price changes (actual and unexpected, respectively) on the actual transition into retirement. The third and fourth specifications consider the effect of housing price changes (actual and unexpected, respectively) on expected retirement age. All four specifications include all controls, including state fixed effects.

Table 8 Column 1 gives results from estimating equation (1), with renters included as a control. The coefficient on the dummy variable Owner is positive, indicating that owners in the sample have a higher annual probability of retirement than renters. The coefficient on the interaction between Owner and the actual cumulative percent change in housing price is 0.00013 , suggesting that a $10 \%$ increase in house price leads to just a $1.2 \%$ increase in annual retirement probability among owners. This result, is significantly smaller than what we found before, and is statistically insignificant. Of perhaps greater interest is the difference in coefficients between owners and renters. This difference is 0.00008 , suggesting that a $10 \%$ increase in real cumulative house price change since 1992 leads to just a $0.75 \%$ increase in the annual probability of retirement. Neither of these coefficients is statistically significant individually, and the difference between them is statistically insignificant. This suggests that housing wealth effects may be much smaller than those suggested by the prior specifications.

Table 8 Column 2 gives results for a specification using unexpected housing price changes. Here we find no housing wealth effect for owners, and no statistically significant difference between owners and renters.

Table 8 Column 3 gives a specification corresponding to Equation (2) that includes renters as a control group and uses actual cumulative percent price increases as the key right- 
hand side variable. In this case, we find that for a $10 \%$ cumulative increase in house prices, expected retirement age among owners declines by about 4 months. This estimate is statistically significant at the 10 percent level. The difference between the wealth effect for owners and renters is -0.04 . If we view this difference-in-difference estimate as giving the true wealth effect for owners, then this suggests that a $10 \%$ cumulative increase in house prices causes a 4.6 month decline expected retirement age. However, it should be noted that the difference in the coefficients between owners and renters are statistically insignificant at conventional levels.

Table 8 Column 4 gives a specification corresponding to Equation (2) that includes renters as a control group and uses unexpected cumulative percent price increases as the key right-hand side variable. In this case, while the coefficient on house price gains for owners is quite large and the difference in coefficients between owners and renters is also quite large, standard errors for the coefficients are large enough that none of the coefficient estimates are statistically significant.

Overall, the findings using renters as a control group are mixed. Housing wealth effects on actual retirement transitions appear to be much smaller than in earlier specifications (possibly nonexistent). Yet we still generally find fairly substantial lowering of expected retirement age in the face of housing wealth gains (though only sometimes statistically significant).

Another potential source of bias in our estimates are unobserved preferences that are correlated with both retirement expectations and wealth. For this reason, we re-estimate Equation 2 with individual-level fixed effects. This is possible because respondents report a new expected retirement age in each wave. Results are given in Table 9. In Columns 1 and 2 we consider the effect of actual cumulative percent changes in house prices and unexpected cumulative percent changes in house prices, respectively, on expected retirement age for the sample of owners. Here 
we see that the magnitude of the wealth effect coefficients suggest that a $10 \%$ increase in housing wealth leads to a decline in expected retirement age of between 4 and 4.5 months.

Renters are included in the sample in Table 9 Columns 3 and 4. In Column 3, we see that a $10 \%$ cumulative increase in house prices leads to a 3.7 month decline in expected retirement age for owners. It has no statistically significant effect on renters, though the difference in coefficients between owners and renters is also statistically insignificant.

The finding in Table 9 Column 4 is somewhat odd. Relative coefficient sizes for owners and renters suggest that renters experience bigger declines in expected retirement age for a given unexpected increase in housing wealth than do owners. This is the opposite of what we would expect, and seems to contradict results displayed elsewhere in Table 9 and throughout the paper. It should be noted, however, that these results are statistically insignificant.

Some work in the literature on housing wealth effects has noted that people respond asymmetrically to gains and losses. In results not shown here we test whether retirement timing responds asymmetrically to increases and decreases in house prices. There is no evidence of such asymmetry.

We also repeat the above analyses on a sample that includes female workers. For households of the generation examined in this paper, males tend to be the primary earner and many women who work in the workplace do so only part time. Our analysis focuses on male workers, because for this generation we expect the effects on male labor force participation to be higher. However, we do consider what happens when women workers are added back into the sample. For the most part, the direction of our findings is similar when women are included, but the magnitude of the effects is smaller. In several cases, results which were statistically significant in the sample of males are of diminished statistical significance when women are 
included. This suggests that women of this generation are making retirement timing decisions that are not as closely tied to housing wealth changes as are the decisions of men of the same generation.

\section{Conclusion and Further Work}

We find evidence, mixed at times, of modest housing wealth effects on retirement timing. The evidence of housing wealth effects on expected age of retirement is stronger than the evidence of housing wealth effects on actual retirement transitions. The difference in the strength of evidence may be due to the right censoring problem associated with examining transitions.

Point estimates of the effect of a $10 \%$ increase in real house price on the annual probability of retirement (by men) range from close to zero to a $6.5 \%$ increase in retirement probability. Point estimates of the effect of a $10 \%$ unexpected increase in real house price on the annual probability of retirement (by men) range from close to zero to a $9 \%$ increase in retirement probability. Overall, the evidence suggests that values closer to the low end of this range may be more plausible.

Evidence that people's expected retirement age declines in housing wealth is stronger. While some point estimates are fairly close to zero, we get point estimates quite consistently in the range of 0.3 to 0.4 , suggesting that a $10 \%$ increase in house value leads to declines in retirement age on the order of 3.5 to 5 months. These results hold up to a number of robustness checks, including inclusion of renters as a control and estimation using individual fixed effects.

It is worth considering whether the financial loss from stopping work 4 months early makes sense, in light of the gain in house value. The mean income among HRS respondents in 
our analysis sample is $\$ 64,000$. So 4 months salary would be about $\$ 21,000$ for the average household. The mean home value in the HRS is $\$ 135,000$, so a $10 \%$ gain is $\$ 13,500$. Given disutility associated with work and the tax liability associated with earned income, it seems plausible that a household would respond to a $\$ 13,500$ gain in untaxed housing wealth by foregoing 4 months of work and the $\$ 21,000$ pre-tax salary associated with that work.

While extrapolating to bigger housing gains requires caution, our findings raise the possibility that individuals in areas with large house-price gains may have substantially revised their retirement timing as a result of housing wealth shocks. While it may be well accepted that labor markets can affect housing markets, our results provide evidence that housing markets can affect local labor markets.

In further work we hope to explore the effect of housing price changes on the labor supply of the already retired. This would include measuring the effect of housing wealth changes on hours worked by the already retired. ${ }^{8}$ This may become a particularly salient issue as the apparent bubble in US housing markets unwinds.

We also intend to investigate different specifications of the unanticipated housing gains variable. We also wish to consider options for distinguishing between transitory and permanent price changes, as suggested by Fisher et al. (2006). Further work with the self-reported house value data in the HRS may allow us to introduce household-level variation in house-price gains. Several predictions of Morris' (2006) paper on housing wealth and consumption lend themselves to tests using data from the HRS. In particular, HRS respondents are asked about propensity to move in retirement and about self-assessed life expectancy. We intend to test a simple extension of Morris's model to optimal retirement timing using these data.

\footnotetext{
${ }^{8}$ Typically, self-declared retirees in the HRS actually work a substantial number of hours each year.
} 
Finally, we plan to explore the mechanism by which house-price gains lead to earlier retirement. For instance, are households accessing new housing wealth through financial markets, as in the case of home equity borrowing? Or, if households are saving for bequests, do housing gains allow them to reach bequest targets sooner and hence allow their members retire earlier? Or can individuals in households with larger housing gains retire earlier because they realize they can rely on children (whose expected bequests have risen) to serve as substitutes for precautionary saving? Data from the HRS on access to financial instruments, bequest intent, and inter vivos transfers will be useful in assessing these questions in further work. 


\section{References}

Ashenfelter, Orley C. and James J. Heckman (1974). "The Estimation of Income and Substitution Effects in a Model of Family Labor Supply." Journal of Labor Economics, 17(4), p757-783.

Belsky, Eric and Joel Prakken (2004). "Housing Wealth Effects: Housing's Impact on Wealth Accumulation, Wealth Distribution, and Consumer Spending." Joint Center for Housing Studies, Harvard University. Working Paper W04-13.

Bhatia, Kul (1987). "Real Estate Assets and Consumer Spending." The Quarterly Journal of Economics. 102 (2).

Bostic, Raphael, Stuart Gabriel and Gary Painter (2005). "Housing Wealth, Financial Wealth, and Consumption: New Evidence from Micro Data." manuscript, University of Southern California.

Burtless, Gary (2000). "How Would Financial Risk Affect Retirement Income Under Individual Accounts?" An Issue in Brief; Center for Retirement Research at Boston College (5).

Calhoun, Charles A. (2006) "OFHEO House Price Indexes: HPI Technical Description.” manuscript, Office of Federal Housing Enterprise Oversight.

Case, Karl E., John M. Quigley, and Robert J. Shiller (2005). "Comparing Wealth Effects: The Stock Market Versus the Housing Market.” Advances in Macroeconomics, 5(1).

Case, Karl E. and Robert J. Shiller (2003). "Is There a Bubble in the Housing Market?" Brookings Papers on Economic Activity, v2003, n2.

Chan, Sewin and Ann Huff Stevens (2004), "Do Changes in Pension Incentives Affect Retirement? A Longitudinal Study of Subjective Retirement Expectations." Journal of Public Economics, v88(7-8): p1307-1333.

Coile, Courtney C. and Jonathan Gruber (2000). "Social Security and Retirement" NBER Working Paper \#7830.

Coronado, Julia Lynn and Maria Perozek, "Wealth Effects and the Consumption of Leisure: Retirement Decisions During the Stock Market Boom of the 1990s," Unpublished Manuscript, 2001.

Disney, Richard, Andrew Henley and David Jevons (2003). "House price shocks, negative equity and household consumption in the UK in the 1990s," manuscript, University of Wales Aberystwyth.

Doling, John and Nick Horsewood (2003). "Home ownership and early retirement: European experience in the 1990s." Journal of Housing and the Built Environment. Vol. 18, p289-308. 
Dynan, Karen E. and Dean M. Maki, (2001), "Does Stock Market Wealth Matter for Consumption?" The Federal Reserve Board Finance and Economics Discussion Series, No. 21.

Engelhardt, Gary V. (2005). "Nominal Loss Aversion, Housing Equity Constraints, and Household Mobility: Evidence from the United States." Journal of Urban Economics (forthcoming).

Engelhardt, Gary V. (1996). "House prices and home owner saving behavior." Regional Science and Urban Economics, 26, p313-336.

Fairlie, Robert W. and Harry A. Krashinsky (2006). "Liquidity Constraints, Household Wealth, and Entrepreneurship Revisited." manuscript, UC Santa Cruz.

Fisher, Lance A, Glenn Otto, Graham M. Voss (2005). "Housing Booms, Non-Financial Wealth and Consumption: Lessons from the Australian Experience." University of Victoria Working Paper.

Gyourko, Joseph, Christopher Mayer, and Todd Sinai (2004). "Superstar Cities." Columbia Business School and Wharton School working paper.

Himmelberg, Charles, Christopher Mayer, and Todd Sinai (2005). "Assessing High House Prices: Bubbles, Fundamentals and Misperceptions.” NBER Working Paper \#11643.

Holtz-Eakin, Douglas, David Joulfaian, and Harvey S. Rosen (1993). "The Carnegie Conjecture: Some Empirical Evidence,” The Quarterly Journal of Economics, 108 (2), p413-435.

Hurd, Michael D. and Michael J. Boskin (1984). "The Effect of Social Security on Retirement in the Early 1970s." The Quarterly Journal of Economics 99(4), p767-790.

Hurd, Michael D. and Monika Reti, "The Effects of Large Capital Gains on Work and Consumption: Evidence from Four Waves of the HRS" RAND Report for the U.S. Department of Labor, October 2001.

Imbens, Guido W., Donald B. Rubin, and Bruce Sacerdote (2001). "Estimating the Effect of Unearned Income on Labor Supply, Earnings, Savings, and Consumption: Evidence from a Survey of Lottery Winners." The American Economic Review 91(4), p778-795.

Kezdi, Gabor and Purvi Sevak (2004). "Economic Adjustment of Recent Retirees to Adverse Wealth Shocks." Michigan Retirement Research Center Working Paper.

Kimball, Miles and Matthew Shapiro (2003). "Labor Supply: Are the Income and Substitution Effects Both Large or Both Small?" University of Michigan Unpublished Manuscript.

Kosters, M. (1966). "Income and Substitution Effects in a Family Labor Supply Model.” Rand Corporation Report \#P-3339. 
Krueger, Alan B. and Jorn-Steffen Pischke (1992). "The Effect of Social Security on Labor Supply: A Cohort Analysis of the Notch Generation," Journal of Labor Economics 10(4), p412-437.

Lehnert, Andreas (2004). "Housing, Consumption and Credit Constraints." The Federal Reserve Board Finance and Economics Discussion Series, No. 63.

Maki, Dean M. and Michael G. Palumbo (2001). "Disentangling the Wealth Effect: A Cohort Analysis of Household Saving in the 1990s." The Federal Reserve Board Finance and Economics Discussion Series, No. 23.

Morris, Erika Dreyer (2006). "Examining the Wealth Effect from Home Price Appreciation." University of Michigan Working Paper.

Pencavel, John. "Labor Supply of Men: A Survey." In Handbook of Labor Economics, Vol. 1. Edited by Orley C. Ashenfelter and Richard Layard. North Holland: Elsevier Science B.V. 1986.

Poterba, James M. (2000). "Stock Market Wealth and Consumption." The Journal of Economics Perspectives, Vol. 14, No. 2, p99-118.

Samwick, Andrew A. (1998). "New Evidence on Pensions, Social Security, and the Timing of Retirement." Journal of Public Economics 70(2), p207-236.

Sevak, Purvi (2005). "Wealth Shocks and Retirement Timing: Evidence from the Nineties." Hunter College Working Paper.

Skinner, J. S. (1996). "Is housing wealth a sideshow?" Advances in the Economics of Aging, National Bureau of Economic Research Report, p241-268. University of Chicago Press.

Stock, James H. and David A. Wise (1990). "Pensions, the Option Value of Work, and Retirement." Econometrica 58(5), p1151-1180.

Venti, Steven F. and David A. Wise (2000). "Aging and Housing Equity." National Bureau of Economic Research Working Paper \#7882. 
Figure 1

Percent HRS Respondents In Analysis Sample Who Have Transitioned to Retirement,

1992-2002

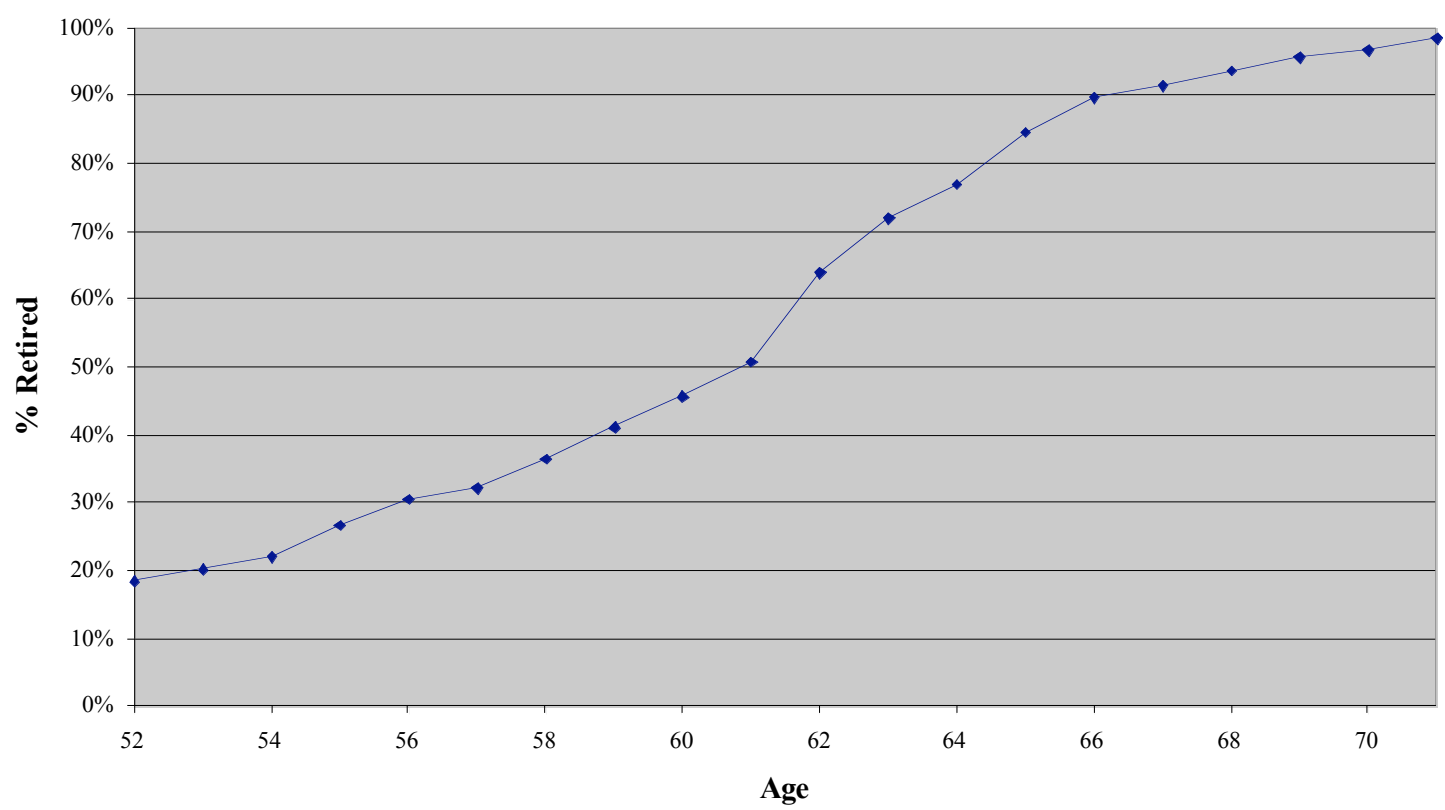

Figure 2

Percent of HRS Respondents in Analysis Sample, by Age at Which they First

Retire

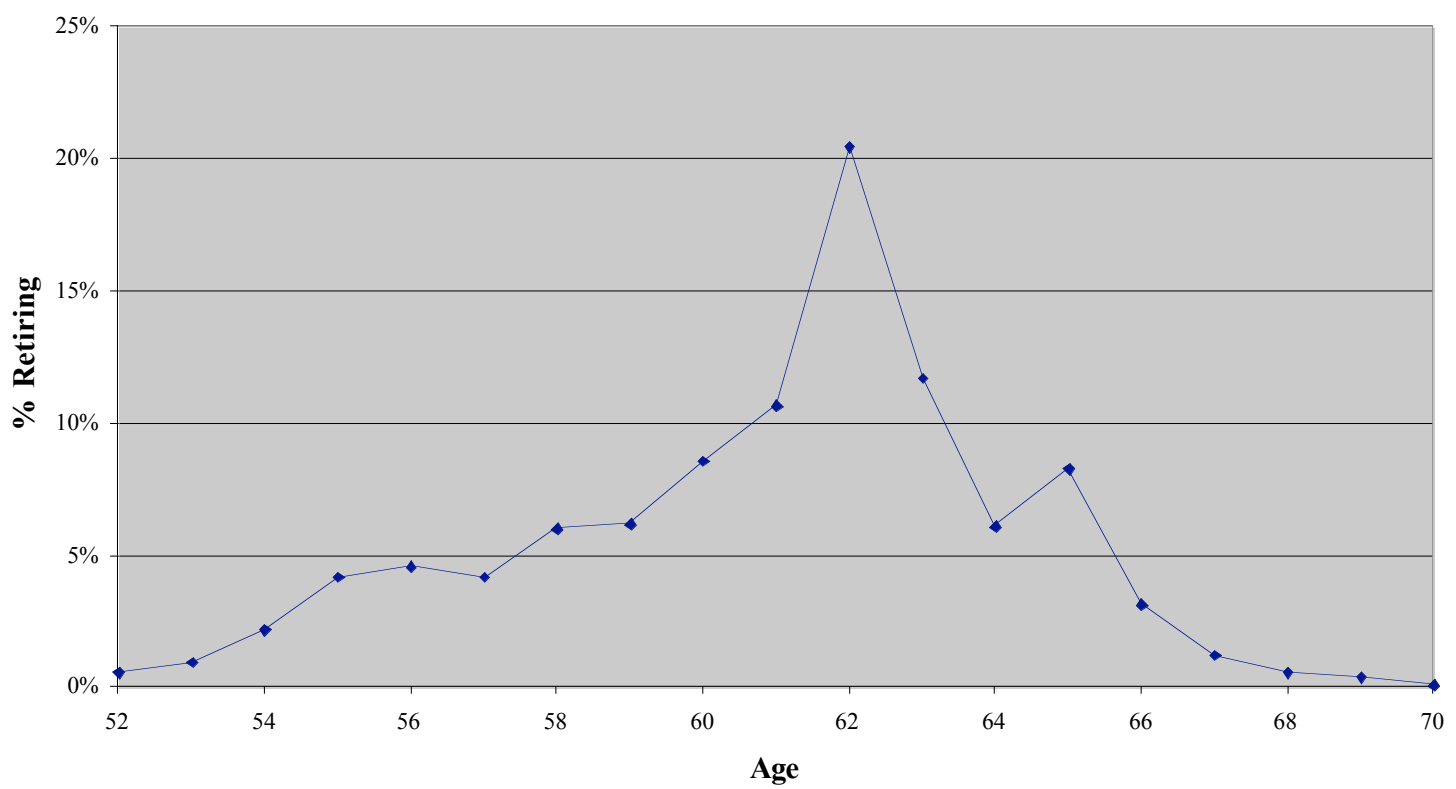


Figure 3. HRS: Actual versus Expected (as of 1992) Retirement Age

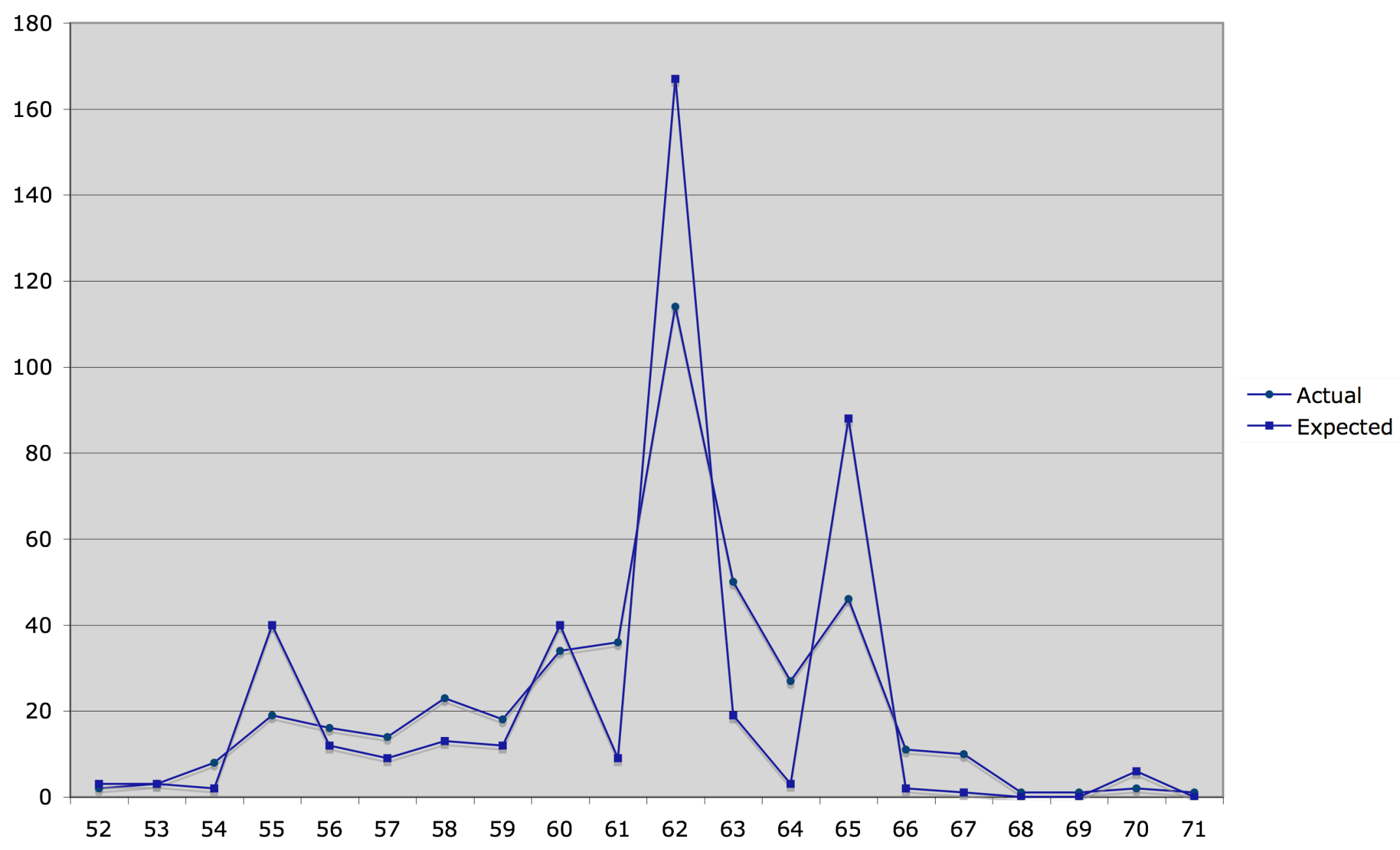


Table 1: Sample Selection Among Male HRS Respondents Born Between 1931 and 1941

\begin{tabular}{|c|c|c|c|c|c|c|}
\hline Year & $\begin{array}{l}\text { Eligible } \\
\text { Men }\end{array}$ & $\begin{array}{l}\text { Not Retired } \\
\text { at } t-1\end{array}$ & $\begin{array}{l}\text { Working } \\
\text { at } \mathrm{t}-1\end{array}$ & $\begin{array}{c}\text { Not Self- } \\
\text { Employed at t-1 }\end{array}$ & $\begin{array}{l}\text { Homeowner } \\
\text { at } \mathrm{t}-1\end{array}$ & $\begin{array}{c}\text { Has No Missing } \\
\text { Data }\end{array}$ \\
\hline 1992 & 4,602 & & & & & \\
\hline 1993 & 4,602 & 3,349 & 3,116 & 2,491 & 1,962 & 1,933 \\
\hline 1994 & 4,602 & 3,146 & 2,938 & 2,340 & 1,840 & 1,666 \\
\hline 1995 & 4,602 & 2,912 & 2,378 & 1,884 & 1,476 & 1,407 \\
\hline 1996 & 4,602 & 2,687 & 2,178 & 1,708 & 1,327 & 1,200 \\
\hline 1997 & 4,602 & 2,455 & 1,847 & 1,450 & 1,176 & 1,122 \\
\hline 1998 & 4,602 & 2,236 & 1,655 & 1,293 & 1,040 & 907 \\
\hline 1999 & 4,602 & 2,037 & 1,385 & 1,079 & 878 & 843 \\
\hline 2000 & 4,602 & 1,820 & 1,200 & 921 & 749 & 665 \\
\hline 2001 & 4,602 & 1,655 & 966 & 743 & 607 & 572 \\
\hline 2002 & 4,602 & 1,486 & 828 & 625 & 510 & 11 \\
\hline 2003 & 4,602 & 1,314 & 635 & 451 & 374 & 0 \\
\hline 2004 & 4,602 & 1,199 & 535 & 367 & 307 & 0 \\
\hline Total & 59,826 & 26,296 & 19,661 & 15,352 & 12,246 & 10,326 \\
\hline
\end{tabular}


Table 2: Summary Statistics for Analysis Sample

\begin{tabular}{lcc}
\hline Age & Mean & Standard Deviation \\
Years of Education & 58.86 & 3.40 \\
Hispanic & 12.69 & 3.16 \\
Black & 0.07 & 0.26 \\
Married (t-1) & 0.12 & 0.33 \\
Poor Health (t-1) & 0.90 & 0.30 \\
Log Wage (t-1) & 0.12 & 0.33 \\
Expected Retirement Age at t-1 & 2.75 & 0.58 \\
Home Equity in 1992 & 63.20 & 4.91 \\
Business Equity in 1992 & 75,748 & 78,060 \\
Other Wealth in 1992 & 13,717 & 137,519 \\
Cumulative \% $\Delta$ House Prices Since 1992 & 95,492 & 251,239 \\
Cumulative Unexpected \% House Prices Since 1992 & 2.55 & 11.13 \\
County Unemployment Rate & -0.71 & 5.37 \\
Sample Size & 0.06 & 0.03 \\
\hline
\end{tabular}

Dollar measures are in year 2000 dollars. Percent changes in house prices are deflated by the CPI (excluding housing).

\section{Table 3: Detailed Distribution of Selected Financial Variables}

\begin{tabular}{|c|c|c|c|c|}
\hline & $\underline{\text { Mean }}$ & 25th Percentile & Median & 75th Percentile \\
\hline Home Equity in 1992 & 75,748 & 30,000 & 55,500 & 98,000 \\
\hline Business Equity in 1992 & 13,717 & 0 & 0 & 0 \\
\hline Other Wealth in 1992 & 95,492 & 13,000 & 38,050 & 95,000 \\
\hline Cumulative \% \% House Prices Since 1992 & 2.55 & -3.41 & 1.31 & 7.67 \\
\hline Cumulative Unexpected \% \% House Prices Since 1992 & -0.71 & -3.22 & -0.51 & 1.93 \\
\hline
\end{tabular}

Dollar measures are in year 2000 dollars. Percent changes in house prices are deflated by the CPI (excluding housing). 
Table 4. OLS Estimates of the

Effect of Changes in House Prices on Men's Retirement Transitions

\begin{tabular}{|c|c|c|c|c|c|c|}
\hline & (1) & & (2) & & (3) & \\
\hline Years of Education & $\begin{array}{l}-0.0003 \\
(0.0015)\end{array}$ & & $\begin{array}{c}0.000 \\
(0.001)\end{array}$ & & $\begin{array}{c}-0.001 \\
(0.001)\end{array}$ & \\
\hline Hispanic & $\begin{array}{l}-0.006 \\
(0.01)\end{array}$ & & $\begin{array}{c}-0.005 \\
(0.016)\end{array}$ & & $\begin{array}{c}-0.004 \\
(0.016)\end{array}$ & \\
\hline Black & $\begin{array}{l}-0.018 \\
(0.01)\end{array}$ & $* *$ & $\begin{array}{l}-0.018 \\
(0.01)\end{array}$ & * & $\begin{array}{c}-0.019 \\
(0.009)\end{array}$ & ** \\
\hline Married (t-1) & $\begin{array}{c}-0.030 \\
(0.013)\end{array}$ & $* *$ & $\begin{array}{l}-0.030 \\
(0.013)\end{array}$ & $* *$ & $\begin{array}{c}-0.031 \\
(0.013)\end{array}$ & ** \\
\hline Poor Health (t-1) & $\begin{array}{c}0.030 \\
(0.011)\end{array}$ & $* *$ & $\begin{array}{c}0.030 \\
(0.011)\end{array}$ & $* *$ & $\begin{array}{c}0.031 \\
(0.012)\end{array}$ & ** \\
\hline Log Wage (t-1) & $\begin{array}{c}0.014 \\
(0.006)\end{array}$ & $* *$ & $\begin{array}{c}0.014 \\
(0.006)\end{array}$ & $* *$ & $\begin{array}{c}0.013 \\
(0.006)\end{array}$ & ** \\
\hline Home Equity (1992, \$1000s) & $\begin{array}{c}0.0001 \\
(0.00004)\end{array}$ & $* *$ & $\begin{array}{c}0.0001 \\
(0.00004)\end{array}$ & $* *$ & $\begin{array}{c}0.0001 \\
(0.00005)\end{array}$ & ** \\
\hline Business Equity (1992, $\$ 1000$ s) & $\begin{array}{l}-0.00003 \\
(0.00002)\end{array}$ & & $\begin{array}{l}-0.00002 \\
(0.00002)\end{array}$ & & $\begin{array}{l}-0.00003 \\
(0.00002)\end{array}$ & \\
\hline Other Wealth $(1992, \$ 1000 s)$ & $\begin{array}{l}0.00001 \\
(0.0002)\end{array}$ & & $\begin{array}{c}0.00001 \\
(0.00002)\end{array}$ & & $\begin{array}{c}0.00001 \\
(0.00002)\end{array}$ & \\
\hline$\% \Delta$ House Prices (since 1992) & $\begin{array}{c}0.0007 \\
(0.0003)\end{array}$ & $* *$ & $\begin{array}{c}0.0007 \\
(0.0003)\end{array}$ & $* *$ & $\begin{array}{c}0.0003 \\
(0.0005)\end{array}$ & \\
\hline County Unemployment Rate & & & $\begin{array}{c}-0.032 \\
(0.136)\end{array}$ & & $\begin{array}{c}0.051 \\
(0.139)\end{array}$ & \\
\hline Age and Year Dummies & $\checkmark$ & & $\checkmark$ & & $\checkmark$ & \\
\hline Industry and Occupation Codes & $\checkmark$ & & $\checkmark$ & & $\checkmark$ & \\
\hline County Unemployment Rate & & & $\checkmark$ & & $\checkmark$ & \\
\hline State Fixed Effects & & & & & $\checkmark$ & \\
\hline$\%$ Retiring & 0.108 & & 0.108 & & 0.108 & \\
\hline $\mathrm{N}$ & 10,326 & & 10,326 & & 10,326 & \\
\hline R-squared & 0.074 & & 0.074 & & 0.079 & \\
\hline
\end{tabular}

** Denotes statistical significance at the $5 \%$ level and * at the $10 \%$ level. Robust standard errors are in parentheses. 
Table 5. OLS Estimates of the Effect of Unexpected Changes in House Prices on Men's Retirement Transitions

\begin{tabular}{|c|c|c|c|c|c|c|}
\hline & (1) & & (2) & & (3) & \\
\hline Years of Education & $\begin{array}{l}-0.0003 \\
(0.0015)\end{array}$ & & $\begin{array}{l}-0.0003 \\
(0.0015)\end{array}$ & & $\begin{array}{l}-0.001 \\
(0.001)\end{array}$ & \\
\hline Hispanic & $\begin{array}{l}-0.008 \\
(0.015)\end{array}$ & & $\begin{array}{l}-0.005 \\
(0.01)\end{array}$ & & $\begin{array}{l}-0.004 \\
(0.016)\end{array}$ & \\
\hline Black & $\begin{array}{l}-0.019 \\
(0.009)\end{array}$ & ** & $\begin{array}{l}-0.019 \\
(0.01)\end{array}$ & ** & $\begin{array}{l}-0.018 \\
(0.009)\end{array}$ & ** \\
\hline Married (t-1) & $\begin{array}{l}-0.028 \\
(0.013)\end{array}$ & ** & $\begin{array}{l}-0.028 \\
(0.013)\end{array}$ & ** & $\begin{array}{l}-0.031 \\
(0.013)\end{array}$ & ** \\
\hline Poor Health (t-1) & $\begin{array}{c}0.031 \\
(0.011)\end{array}$ & ** & $\begin{array}{c}0.030 \\
(0.011)\end{array}$ & ** & $\begin{array}{c}0.031 \\
(0.012)\end{array}$ & ** \\
\hline Log Wage (t-1) & $\begin{array}{c}0.013 \\
(0.006)\end{array}$ & *** & $\begin{array}{c}0.013 \\
(0.006)\end{array}$ & ** & $\begin{array}{c}0.013 \\
(0.006)\end{array}$ & ** \\
\hline Home Equity $(1992, \$ 1000$ s) & $\begin{array}{c}0.0001 \\
(0.00005)\end{array}$ & ** & $\begin{array}{c}0.0001 \\
(0.00005)\end{array}$ & $* *$ & $\begin{array}{c}0.000 \\
(0.00005)\end{array}$ & ** \\
\hline Business Equity (1992, \$1000s) & $\begin{array}{l}-0.00002 \\
(0.00002)\end{array}$ & & $\begin{array}{l}-0.00002 \\
(0.00002)\end{array}$ & & $\begin{array}{l}-0.00003 \\
(0.00002)\end{array}$ & \\
\hline Other Wealth $(1992, \$ 1000 \mathrm{~s})$ & $\begin{array}{l}0.00002 \\
(0.0002)\end{array}$ & & $\begin{array}{c}0.00002 \\
(0.00002)\end{array}$ & & $\begin{array}{c}0.00001 \\
(0.00002)\end{array}$ & \\
\hline Unexpected $\% \Delta$ House Prices (since 1992) & $\begin{array}{c}0.0010 \\
(0.0005)\end{array}$ & ** & $\begin{array}{c}0.0011 \\
(0.0005)\end{array}$ & ** & $\begin{array}{c}0.0009 \\
(0.0006)\end{array}$ & \\
\hline County Unemployment Rate & & & $\begin{array}{l}-0.093 \\
(0.120)\end{array}$ & & $\begin{array}{c}0.034 \\
(0.134)\end{array}$ & \\
\hline Age and Year Dummies & $\checkmark$ & & $\checkmark$ & & $\checkmark$ & \\
\hline Industry and Occupation Codes & $\checkmark$ & & $\checkmark$ & & $\checkmark$ & \\
\hline County Unemployment Rate & & & $\checkmark$ & & $\checkmark$ & \\
\hline State Fixed Effects & & & & & $\checkmark$ & \\
\hline$\%$ Retiring & 0.108 & & 0.108 & & 0.108 & \\
\hline $\mathrm{N}$ & 10,326 & & 10,326 & & 10,326 & \\
\hline R-squared & 0.074 & & 0.074 & & 0.079 & \\
\hline
\end{tabular}

** Denotes statistical significance at the $5 \%$ level and * at the $10 \%$ level. Robust standard errors are in parentheses. 
Table 6. OLS Estimates of the

Effect of Changes in House Prices on Men's Expected Retirement Age

\begin{tabular}{|c|c|c|c|c|c|c|}
\hline \multirow[b]{2}{*}{ Years of Education } & \multicolumn{2}{|l|}{$(1)$} & \multicolumn{2}{|l|}{$(2)$} & \multicolumn{2}{|l|}{$(3)$} \\
\hline & $\begin{array}{c}0.097 \\
(0.033)\end{array}$ & $* *$ & $\begin{array}{c}0.098 \\
(0.033)\end{array}$ & $* *$ & $\begin{array}{c}0.091 \\
(0.037)\end{array}$ & $* *$ \\
\hline Hispanic & $\begin{array}{c}-0.015 \\
(0.359)\end{array}$ & & $\begin{array}{l}-0.100 \\
(0.356)\end{array}$ & & $\begin{array}{c}-0.538 \\
(0.459)\end{array}$ & \\
\hline Black & $\begin{array}{c}-0.424 \\
(0.187)\end{array}$ & $* *$ & $\begin{array}{c}-0.431 \\
(0.188)\end{array}$ & $* *$ & $\begin{array}{l}-0.328 \\
(0.248)\end{array}$ & \\
\hline Married (t-1) & $\begin{array}{c}0.448 \\
(0.269)\end{array}$ & $*$ & $\begin{array}{c}0.453 \\
(0.269)\end{array}$ & * & $\begin{array}{l}0.418 \\
(0.3)\end{array}$ & \\
\hline Poor Health (t-1) & $\begin{array}{c}-0.360 \\
(0.192)\end{array}$ & * & $\begin{array}{c}-0.358 \\
(0.193)\end{array}$ & * & $\begin{array}{c}-0.331 \\
(0.215)\end{array}$ & * \\
\hline Log Wage (t-1) & $\begin{array}{l}-0.646 \\
(0.204)\end{array}$ & $* *$ & $\begin{array}{l}-0.642 \\
(0.204)\end{array}$ & $* *$ & $\begin{array}{l}-0.676 \\
(0.188)\end{array}$ & ** \\
\hline Home Equity (1992, \$1000s) & $\begin{array}{l}-0.003 \\
(0.001)\end{array}$ & $*$ & $\begin{array}{l}-0.002 \\
(0.001)\end{array}$ & $*$ & $\begin{array}{l}-0.002 \\
(0.001)\end{array}$ & \\
\hline Business Equity $(1992, \$ 1000 s)$ & $\begin{array}{l}-0.0002 \\
(0.0004)\end{array}$ & & $\begin{array}{l}-0.0002 \\
(0.0004)\end{array}$ & & $\begin{array}{l}-0.0003 \\
(0.0005)\end{array}$ & \\
\hline Other Wealth $(1992, \$ 1000 \mathrm{~s})$ & $\begin{array}{c}0.0003 \\
(0.0003)\end{array}$ & & $\begin{array}{c}0.0003 \\
(0.0003)\end{array}$ & & $\begin{array}{c}0.0002 \\
(0.0003)\end{array}$ & \\
\hline$\% \Delta$ House Prices (since 1992) & $\begin{array}{c}-0.033 \\
(0.008)\end{array}$ & $* *$ & $\begin{array}{c}-0.032 \\
(0.008)\end{array}$ & $* *$ & $\begin{array}{c}-0.027 \\
(0.011)\end{array}$ & ** \\
\hline County Unemployment Rate & & & $\begin{array}{c}2.65 \\
(3.02)\end{array}$ & & $\begin{array}{l}-1.66 \\
(3.48)\end{array}$ & \\
\hline Age and Year Dummies & $\checkmark$ & & $\checkmark$ & & $\checkmark$ & \\
\hline Industry and Occupation Codes & $\checkmark$ & & $\checkmark$ & & $\checkmark$ & \\
\hline County Unemployment Rate & & & $\checkmark$ & & $\checkmark$ & \\
\hline State Fixed Effects & & & & & $\checkmark$ & \\
\hline Mean Expected Retirement Age & 63.2 & & 63.2 & & 63.2 & \\
\hline $\mathrm{N}$ & 7,427 & & 7,427 & & 7,427 & \\
\hline R-squared & 0.193 & & 0.193 & & 0.203 & \\
\hline
\end{tabular}

** Denotes statistical significance at the $5 \%$ level and * at the $10 \%$ level. Robust standard errors are in parentheses. 
Table 7. OLS Estimates of the

Effect of Unexpected Changes in House Prices on Men's Expected Retirement Age

\begin{tabular}{|c|c|c|c|c|c|c|}
\hline \multirow[b]{2}{*}{ Years of Education } & \multicolumn{2}{|l|}{ (1) } & \multicolumn{2}{|l|}{ (2) } & \multicolumn{2}{|l|}{ (3) } \\
\hline & $\begin{array}{c}0.098 \\
(0.034)\end{array}$ & ** & $\begin{array}{c}0.098 \\
(0.033)\end{array}$ & ** & $\begin{array}{c}0.091 \\
(0.034)\end{array}$ & ** \\
\hline Hispanic & $\begin{array}{c}0.093 \\
(0.383)\end{array}$ & & $\begin{array}{l}-0.104 \\
(0.372)\end{array}$ & & $\begin{array}{l}-0.564 \\
(0.414)\end{array}$ & \\
\hline Black & $\begin{array}{l}-0.362 \\
(0.186)\end{array}$ & * & $\begin{array}{l}-0.383 \\
(0.187)\end{array}$ & ** & $\begin{array}{l}-0.343 \\
(0.203)\end{array}$ & * \\
\hline Married (t-1) & $\begin{array}{c}0.367 \\
(0.264)\end{array}$ & & $\begin{array}{c}0.382 \\
(0.265)\end{array}$ & & $\begin{array}{c}0.417 \\
(0.279)\end{array}$ & \\
\hline Poor Health (t-1) & $\begin{array}{l}-0.396 \\
(0.188)\end{array}$ & $* *$ & $\begin{array}{l}-0.391 \\
(0.189)\end{array}$ & ** & $\begin{array}{l}-0.340 \\
(0.187)\end{array}$ & * \\
\hline Log Wage (t-1) & $\begin{array}{l}-0.613 \\
(0.206)\end{array}$ & $* *$ & $\begin{array}{l}-0.608 \\
(0.206)\end{array}$ & ** & $\begin{array}{l}-0.676 \\
(0.193)\end{array}$ & ** \\
\hline Home Equity (1992, \$1000s) & $\begin{array}{c}-0.002 \\
(0.0014)\end{array}$ & & $\begin{array}{c}-0.002 \\
(0.0014)\end{array}$ & & $\begin{array}{c}-0.002 \\
(0.0014)\end{array}$ & \\
\hline Business Equity (1992, $\$ 1000$ s) & $\begin{array}{c}-0.0003 \\
(0.0004)\end{array}$ & & $\begin{array}{c}-0.0003 \\
(0.0004)\end{array}$ & & $\begin{array}{l}-0.0002 \\
(0.0005)\end{array}$ & \\
\hline Other Wealth $(1992, \$ 1000 \mathrm{~s})$ & $\begin{array}{c}0.0002 \\
(0.0003)\end{array}$ & & $\begin{array}{c}0.0002 \\
(0.0003)\end{array}$ & & $\begin{array}{c}0.0002 \\
(0.0003)\end{array}$ & \\
\hline$\% \Delta$ House Prices (since 1992) & $\begin{array}{l}-0.053 \\
(0.013)\end{array}$ & $* *$ & $\begin{array}{l}-0.054 \\
(0.013)\end{array}$ & ** & $\begin{array}{l}-0.052 \\
(0.014)\end{array}$ & ** \\
\hline County Unemployment Rate & & & $\begin{array}{c}5.59 \\
(3.20)\end{array}$ & $*$ & $\begin{array}{c}-0.90 \\
(3.53)\end{array}$ & \\
\hline Age and Year Dummies & $\checkmark$ & & $\checkmark$ & & $\checkmark$ & \\
\hline Industry and Occupation Codes & $\checkmark$ & & $\checkmark$ & & $\checkmark$ & \\
\hline County Unemployment Rate & & & $\checkmark$ & & $\checkmark$ & \\
\hline State Fixed Effects & & & & & $\checkmark$ & \\
\hline Mean Expected Retirement Age & 63.2 & & 63.2 & & 63.2 & \\
\hline $\mathrm{N}$ & 7,427 & & 7,427 & & 7,427 & \\
\hline R-squared & 0.192 & & 0.193 & & 0.205 & \\
\hline
\end{tabular}

** Denotes statistical significance at the $5 \%$ level and * at the $10 \%$ level. Robust standard errors are in parentheses. 
Table 8. Owners vs. Renters: OLS Estimates of the Effect of Changes in House Prices on Men's Retirement Transitions and Expected Retirement Age

\begin{tabular}{|c|c|c|c|c|c|c|c|c|}
\hline & (1) & & $(2)$ & & $(3)$ & & (4) & \\
\hline Dependent Variable & Retire $=1$ & & Retire $=1$ & & E[Ret. Age] & & E[Ret. Age] & \\
\hline Years of Education & $\begin{array}{c}-0.001 \\
(0.001)\end{array}$ & & $\begin{array}{l}-0.001 \\
(0.001)\end{array}$ & & $\begin{array}{c}0.082 \\
(0.030)\end{array}$ & $* *$ & $\begin{array}{c}0.082 \\
(0.030)\end{array}$ & ** \\
\hline Hispanic & $\begin{array}{c}0.002 \\
(0.011)\end{array}$ & & $\begin{array}{c}0.003 \\
(0.011)\end{array}$ & & $\begin{array}{l}-0.371 \\
(0.305)\end{array}$ & & $\begin{array}{l}-0.393 \\
(0.307)\end{array}$ & \\
\hline Black & $\begin{array}{l}-0.015 \\
(0.008)\end{array}$ & * & $\begin{array}{c}-0.014 \\
(0.008)\end{array}$ & * & $\begin{array}{l}-0.442 \\
(0.218)\end{array}$ & ** & $\begin{array}{l}-0.468 \\
(0.219)\end{array}$ & ** \\
\hline Married (t-1) & $\begin{array}{l}-0.020 \\
(0.009)\end{array}$ & $* *$ & $\begin{array}{l}-0.020 \\
(0.009)\end{array}$ & ** & $\begin{array}{c}0.459 \\
(0.224)\end{array}$ & $* *$ & $\begin{array}{c}0.449 \\
(0.223)\end{array}$ & $* *$ \\
\hline Poor Health (t-1) & $\begin{array}{c}0.030 \\
(0.009)\end{array}$ & $* *$ & $\begin{array}{c}0.030 \\
(0.009)\end{array}$ & $* *$ & $\begin{array}{l}-0.443 \\
(0.176)\end{array}$ & $* *$ & $\begin{array}{l}-0.446 \\
(0.174)\end{array}$ & $* *$ \\
\hline Log Wage (t-1) & $\begin{array}{c}0.011 \\
(0.006)\end{array}$ & $* *$ & $\begin{array}{c}0.011 \\
(0.006)\end{array}$ & $* *$ & $\begin{array}{l}-0.549 \\
(0.168)\end{array}$ & $* *$ & $\begin{array}{l}-0.544 \\
(0.168)\end{array}$ & $* *$ \\
\hline Home Equity (1992, \$1000s) & $\begin{array}{c}0.0001 \\
(0.00004)\end{array}$ & $* *$ & $\begin{array}{c}0.0001 \\
(0.00004)\end{array}$ & $* *$ & $\begin{array}{l}-0.003 \\
(0.001)\end{array}$ & $*$ & $\begin{array}{l}-0.003 \\
(0.001)\end{array}$ & * \\
\hline Business Equity (1992, $\$ 1000$ s) & $\begin{array}{l}-0.00002 \\
(0.00002)\end{array}$ & & $\begin{array}{l}-0.00002 \\
(0.00002)\end{array}$ & & $\begin{array}{l}-0.0002 \\
(0.0004)\end{array}$ & & $\begin{array}{l}-0.0003 \\
(0.0004)\end{array}$ & \\
\hline Other Wealth (1992, \$1000s) & $\begin{array}{c}0.00002 \\
(0.00002)\end{array}$ & & $\begin{array}{c}0.00002 \\
(0.00002)\end{array}$ & & $\begin{array}{c}0.0001 \\
(0.0003)\end{array}$ & & $\begin{array}{c}0.0001 \\
(0.0003)\end{array}$ & \\
\hline Owner & $\begin{array}{c}0.01762 \\
(0.007)\end{array}$ & $* *$ & $\begin{array}{c}0.01811 \\
(0.008)\end{array}$ & $* *$ & $\begin{array}{c}-0.6220 \\
(0.237)\end{array}$ & $* *$ & $\begin{array}{c}-0.7019 \\
(0.236)\end{array}$ & ** \\
\hline \multicolumn{9}{|l|}{ Actual \% $\%$ House Prices (since 1992) } \\
\hline Owners & $\begin{array}{l}0.00013 \\
(0.0009)\end{array}$ & & & & $\begin{array}{c}-0.03139 \\
(0.019)\end{array}$ & * & & \\
\hline Renters & $\begin{array}{l}0.00005 \\
(0.0009)\end{array}$ & & & & $\begin{array}{c}0.00667 \\
(0.020)\end{array}$ & & & \\
\hline \multicolumn{9}{|c|}{ Unexpected $\% \Delta$ House Prices (since 1992) } \\
\hline Owners & & & $\begin{array}{c}0.001 \\
(0.001)\end{array}$ & & & & $\begin{array}{l}-0.040 \\
(0.033)\end{array}$ & \\
\hline Renters & & & $\begin{array}{c}0.000 \\
(0.001)\end{array}$ & & & & $\begin{array}{l}-0.001 \\
(0.033)\end{array}$ & \\
\hline County Unemployment Rate & $\begin{array}{c}0.030 \\
(0.110)\end{array}$ & & $\begin{array}{c}0.021 \\
(0.106)\end{array}$ & & $\begin{array}{l}-1.68 \\
(3.49)\end{array}$ & & $\begin{array}{l}-1.62 \\
(3.27)\end{array}$ & \\
\hline Mean of Dependent Variable & 0.108 & & 0.108 & & 63.2 & & 63.2 & \\
\hline $\mathrm{N}$ & 12,816 & & 12,816 & & 8,943 & & 8,943 & \\
\hline R-squared & 0.079 & & 0.079 & & 0.203 & & 0.209 & \\
\hline
\end{tabular}

** Denotes statistical significance at the $5 \%$ level and * at the $10 \%$ level. Robust standard errors are in parentheses.

All specifications include controls for age and year, industry and occupation, county unemployment rate, and state fixed effects. 
Table 9. Fixed Effects Estimates of the

Effect of Changes in House Price on Men's Expected Retirement Age

\begin{tabular}{|c|c|c|c|c|c|c|c|c|c|}
\hline & & \multicolumn{3}{|c|}{ Owners } & & \multicolumn{3}{|c|}{ Owners and Renters } & \\
\hline & & $(1)$ & & $(2)$ & & (3) & & (4) & \\
\hline Married (t-1) & & $\begin{array}{c}0.039 \\
(0.399)\end{array}$ & & $\begin{array}{c}0.045 \\
(0.399)\end{array}$ & & $\begin{array}{c}0.309 \\
(0.314)\end{array}$ & & $\begin{array}{c}0.314 \\
(0.314)\end{array}$ & \\
\hline Poor Health (t-1) & & $\begin{array}{l}-0.339 \\
(0.211)\end{array}$ & & $\begin{array}{l}-0.357 \\
(0.212)\end{array}$ & & $\begin{array}{c}-0.373 \\
(0.199)\end{array}$ & * & $\begin{array}{c}-0.393 \\
(0.199)\end{array}$ & * \\
\hline Log Wage (t-1) & & $\begin{array}{c}-0.086 \\
(0.197)\end{array}$ & & $\begin{array}{l}-0.086 \\
(0.197)\end{array}$ & & $\begin{array}{c}-0.094 \\
(0.181)\end{array}$ & & $\begin{array}{l}-0.090 \\
(0.181)\end{array}$ & \\
\hline Owner & & & & & & $\begin{array}{c}0.480 \\
(0.242)\end{array}$ & $* *$ & $\begin{array}{c}0.406 \\
(0.241)\end{array}$ & \\
\hline \multicolumn{9}{|c|}{ Actual $\% \Delta$ House Prices (since 1992) } & \\
\hline & Owners & $\begin{array}{l}-0.032 \\
(0.009)\end{array}$ & $* *$ & & & $\begin{array}{c}-0.031 \\
(0.015)\end{array}$ & $* *$ & & \\
\hline & Renters & & & & & $\begin{array}{c}-0.003 \\
(0.015)\end{array}$ & & & \\
\hline \multicolumn{10}{|c|}{ Unexpected $\% \Delta$ House Prices (since 1992) } \\
\hline & Owners & & & $\begin{array}{c}-0.038 \\
(0.013)\end{array}$ & $* *$ & & & $\begin{array}{l}0.0001 \\
(0.027)\end{array}$ & \\
\hline & Renters & & & & & & & $\begin{array}{l}-0.034 \\
(0.026)\end{array}$ & \\
\hline County Unemployment Rate & & $\begin{array}{c}1.95 \\
(0.01)\end{array}$ & & $\begin{array}{c}0.83 \\
(5.57)\end{array}$ & & $\begin{array}{c}7.40 \\
(5.18)\end{array}$ & & $\begin{array}{c}5.67 \\
(5.15)\end{array}$ & \\
\hline Mean Expected Retirement Age & & 63.2 & & 63.2 & & 63.2 & & 63.2 & \\
\hline $\mathrm{N}$ & & 7,432 & & 7,432 & & 8,966 & & 8,966 & \\
\hline R-squared & & 0.057 & & 0.055 & & 0.044 & & 0.039 & \\
\hline
\end{tabular}

** Denotes statistical significance at the $5 \%$ level and * at the $10 \%$ level. Robust standard errors are in parentheses. 